\title{
General Business Model Patterns for Local Energy Management Concepts
}

\author{
Emanuele Facchinetti ${ }^{\star}$ and Sabine Sulzer \\ Lucerne Competence Center for Energy Research, Lucerne University of Applied Science and Arts, Horw, Switzerland
}

OPEN ACCESS

Edited by:

Léo Benichou,

The Shift Project, France

Reviewed by:

Pierre Serkine,

KIC InnoEnergy SE, Belgium

Eric Vidalenc,

Agence de l'Environnement et de la

Maitrise de l'Energie, France

*Correspondence:

Emanuele Facchinetti

emanuele.facchinetti@hslu.ch

Specialty section:

This article was submitted to Energy

Systems and Policy,

a section of the journal

Frontiers in Energy Research

Received: 03 December 2015

Accepted: 12 February 2016

Published: 03 March 2016

Citation:

Facchinetti E and Sulzer S (2016)

General Business Model

Patterns for Local Energy

Management Concepts.

Front. Energy Res. 4:7.

doi: 10.3389/fenrg.2016.00007
The transition toward a more sustainable global energy system, significantly relying on renewable energies and decentralized energy systems, requires a deep reorganization of the energy sector. The way how energy services are generated, delivered, and traded is expected to be very different in the coming years. Business model innovation is recognized as a key driver for the successful implementation of the energy turnaround. This work contributes to this topic by introducing a heuristic methodology easing the identification of general business model patterns best suited for Local Energy Management concepts such as Energy Hubs. A conceptual framework characterizing the Local Energy Management business model solution space is developed. Three reference business model patterns providing orientation across the defined solution space are identified, analyzed, and compared. Through a market review, a number of successfully implemented innovative business models have been analyzed and allocated within the defined solution space. The outcomes of this work offer to potential stakeholders a starting point and guidelines for the business model innovation process, as well as insights for policy makers on challenges and opportunities related to Local Energy Management concepts.

Keywords: local energy management, energy hub, business models, business innovation, decentralized energy systems, distributed generation, renewable energy, energy market

\section{INTRODUCTION}

The diffusion of decentralized energy systems is expected to provide a significant contribution toward a more sustainable global energy system and to the achievement of the international greenhouse gases reduction targets (Viral and Khatod, 2012; IEA, 2014). A fast growing interest on the transition from the conventional centralized power generation toward distributed generation can be observed in many industrialized countries (IEA, 2002; Karger and Hennings, 2009; Allan et al., 2015). Having set very ambitious sustainability targets within the European Commission's Energy Road Map 2050 (European Commission, 2011), Europe emerges as a leader of the energy transition. Appropriate measures and policies have been deployed to achieve these targets (European Commission, 2012, 2014). In particular, the recent adoption of the Energy Union strategy (European Commission, 2015a), with the aim to fully integrate the internal energy market, represents a major step ahead toward the transformation of Europe's energy system.

The major driving forces behind the growth of distributed generation are: the liberalization of electricity and gas markets, facilitated by the significant cost reduction for information and communication technologies (ICT); the trend toward energy services densification driven by the increasing urban density; the significant increase of the intrinsically distributed renewable energy; and the avoidance of new high voltage transmission lines (Viral and Khatod, 2012; Allan et al., 2015). The distributed generation development is expected to provide major impacts on 
energy efficiency increase and emission reduction especially on the building sector that according to the International Energy Agency (IEA, 2014) accounts for more than 30\% of the world total energy consumption. This share strongly increases in industrialized countries, being for instance more than $45 \%$ in Switzerland (SFOE, 2012).

At urban scale, many scientific works have acknowledged the environomic (i.e., thermodynamic, economic, and environmental) advantage of decentralized advanced multi-energy systems with respect to conventional centralized energy systems (Capuder and Mancarella, 2014; Mancarella, 2014; Orehounig et al., 2014). In the future, advanced multi energy systems are expected to harmonize the integration of increasing share of fluctuating renewable energy generation together with the interactions of many advanced energy conversion and storage technologies, operating across different energy carriers, and capable of a more rational conversion of bio and fossil fuels (Weber and Favrat, 2010; Graves et al., 2011; Facchinetti et al., 2014). In the literature, these concepts of Local Energy Management - the management of energy supply, demand and storage within a given geographical area - are referred to in many different ways (Mancarella, 2014). A concept well established within the scientific community and comprehensively encompassing every possible declination of Local Energy Management approach is the Energy Hub (Geidl et al., 2007; Parisio et al., 2012; Orehounig et al., 2014, 2015). The Energy Hub concept was first introduced by Geidl et al. (2007) as a conceptual model of an energy system operating across multi energy carriers (i.e., electricity, thermal, and chemical energies) through the optimal management and integration of energy conversion and storage technologies.

The transition toward more sustainable energy systems, significantly relying on the deployment of Energy Hub concepts, requires a deep reorganization of the power generation sector. The power generation sector and its stakeholders stand today at the starting point of a challenging revolution: the way how energy services are generated, delivered, and traded is expected to be very different in the coming years (Frei, 2008; SchleicherTappeser, 2012).

Currently, utility companies substantially control the energy market, especially regarding the electricity sector. With their dominant market position and influence on policy makers (i.e., continuous lobby activities), utilities are expected to play a major role on the energy transition (Sühlsen and Hisschemöller, 2014). In order to compete in this changing environment, they need to face the challenge of creating new successful business models (Frei, 2008; Schleicher-Tappeser, 2012).

In this regard, a number of scientific works have recently focused on new business models for renewable energies and distributed generation. Richter (2012) reviewed the current state of the literature on utilities business models for renewable energy, proposed two generic business models suitable for renewable energy, and highlighted the emerging barriers and opportunities for utilities. The study concludes that despite the fact that business models related to large-scale projects currently comprise less risks and better returns, utilities should strategically increase their capability in the field of business model innovation to exploit the business opportunities offered by small-scale distributed generation. The same author recently analyzed the applicability and potential on the German market of the two generic business models interviewing a large number of German utility managers (Richter, 2013). The outcome of this work outlines how utility managers developed business model for large-scale renewable based business while at the same time they struggled to identify adequate business models at small scales typical of distributed generation. Loock (2012) reported the results of choice experiments with investment managers for renewable energy aiming to identify their investment preferences. A clearly emerging outcome is the fact that business models proposing best services are considered more attractive than business models oriented to low price and best technologies. Curtius et al. (2012) explored the customer segmentation for smart grids on the basis of a European study and derived a number of generic business models best suited to address the different customer segments. Furthermore, this work highlighted that no single business model can guarantee the successful penetration of smart grids. Instead, various business model characterized by optimized value propositions matching the heterogeneous customer value perceptions should be developed.

In the last years, the scientific community clearly outlined the strategic role of business model innovation to guarantee the efficient implementation of the energy turnaround. This work contributes to this topic by introducing a heuristic methodology easing the identification of general business model patterns best suited for Energy Hub concepts. A conceptual framework characterizing the Energy Hub business model solution space is developed. Three reference business model patterns providing orientation across the defined solution space are identified, analyzed, and compared. ${ }^{1}$ Through a market review, a number of successfully implemented innovative business models have been analyzed and allocated within the defined solution space. The conceptual framework has been developed to comprehensively embrace and be generally applicable to any form of Local Energy Management concepts spanning from basic single energy carrier Energy Hubs (e.g., a platform connecting photovoltaic prosumers to the energy market), to very complex multi energy carriers Energy Hubs (e.g., involving conversion across electricity, thermal, and chemical carriers). The outcomes of this work offer to potential Energy Hub stakeholders a starting point and guidelines for the required business model innovation process, as well as insights for policy makers on challenges and opportunities related to Energy Hub concepts.

The paper is organized as follows: in Section "Methods," the applied heuristic methodology is described and the Energy Hub business model solution space is defined. In Section "Results and Discussion," the selected reference business model patterns are presented and discussed. Furthermore, the outcomes of the market review are presented. Finally, in Section "Conclusion," energy policy implications are outlined.

${ }^{1}$ The evaluation of their market efficiency is out of the scope of this work. 


\section{METHODS}

Business model innovation is recognized to be a challenging multidimensional and interdisciplinary process strongly reliant on experimentation (Chesbrough, 2010; Richter, 2013; Gassmann et al., 2014). Objective of the heuristic methodology presented here is to define a conceptual framework supporting the business model innovation process for Energy Hub at the early stage. The methodology enables to identify potentially interesting business model ideas and organize them in patterns aligned with the Energy Hub value chain. The obtained business model patterns are meant to be further developed, refined, and adapted through implementation and testing in order to complete the business model innovation process.

\section{The Energy Hub and Its Value Chain}

The Energy Hub is a broad concept encompassing every possible form of Local Energy Management approach. From the energy perspective, the Energy Hub is an entity operating within a given geographical area and across multiple energy carriers (i.e., electricity, thermal, and chemical) that guarantees the energy supply to meet the demand through the optimized management of internal flexibilities and energy market participation. From the business perspective the Energy Hub is an entity potentially operated by utilities, aggregators, ESCOs or public bodies, which connects consumers, prosumers, and partners (i.e., neighbor Energy Hub, industry, utilities) to each other and with the wholesale energy market (Figure 1).

The Energy Hub value chain is used as a key driver through the heuristic methodology presented in the next section and therefore it is characterized first. The value chain of a business is defined as the number of activities to be performed to generate the value proposition offered to the customer (Porter, 1985). From the business point of view, the Energy Hub is a provider of energy services that guarantees the energy supply to meet the demand through the optimized management of the internal flexibilities

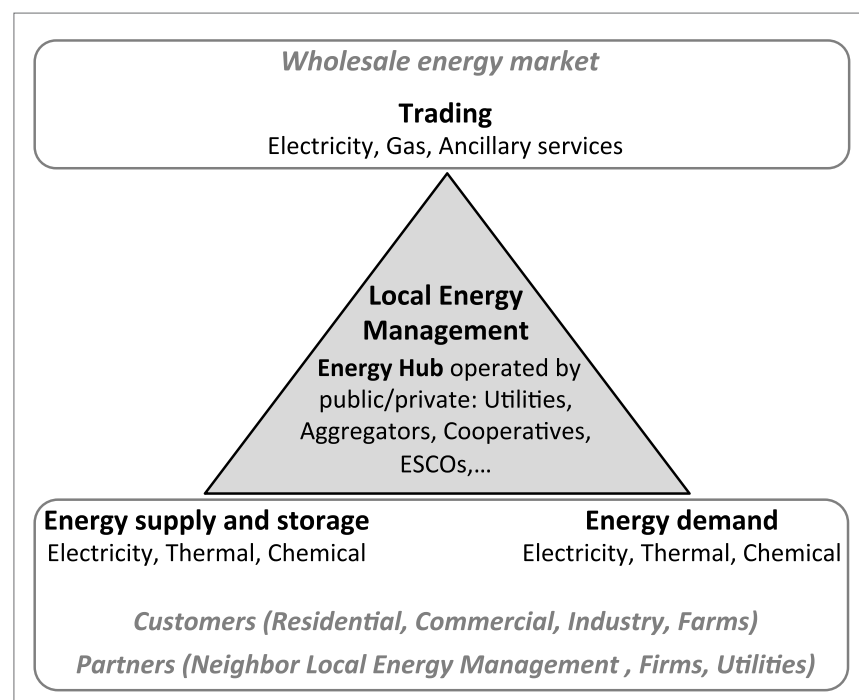

FIGURE 1 | Local energy management concept. and through the participation in the energy market. Possibly, the Energy Hub offers value-added services going beyond the energy services supply. The Energy Hub value chain characterized by the authors can be described by five activities, which are detailed hereafter.

The Acquisition/Loyalty refers to the establishment of relationships with customers and partners of the business. Customers of Energy Hubs could be consumers or prosumers of energy services. Partners can be companies dealing with energy generation, conversion, storage, or transmission technologies as well as financing or trading institutes or other Energy Hubs operating in the proximity.

The Procurement of Infrastructure refers to the need of exploiting infrastructures for the production, storage, conversion, and delivery of energy services. ICT and ancillary systems are also required.

The Operation and Control of Infrastructures refers to the need of constantly operate, control, and maintain the exploited infrastructure. This activity includes also the balancing within the Energy Hub grid and with the external grids by offering ancillary services.

The Delivery of Energy Services comprises the secure delivery of energy to customers from the generation within or outside an Energy Hub. Delivery of complementary services going beyond energy supply, e.g., domestic services and mobility solutions, is also part of this activity. Furthermore, this activity includes the metering intended as the accounting of the energy exchanged.

The Pricing comprises administrative tasks such as, the establishment of prices, the communication with the customers and the partners, the contracting, the billing, and the account of trading costs and revenues.

\section{The Heuristic Methodology}

In the rather young research field of business model innovation the Business Model Navigator approach, recently introduced by Gassmann et al. (2014), emerges as an original and promising attempt to develop a comprehensive and systematic conceptual framework. Such framework has been used as starting point for the developed heuristic methodology.

Relying on an extensive experience on business innovation including collaborations with a variety of partner firms (Gassmann et al., 2010; Bucherer et al., 2012), within the Business Model Navigator Gassmann et al. (2014) analyzed the vast majority of all successfully deployed business models across all market sectors in the last 25 years. As an outcome of this analysis, they recognized that about $90 \%$ of such business models were not created from disruptive ideas, but they were rather a recombination of 55 recurring basic business model ideas. With this significant conclusion, Gassmann et al. showed that, even though creativity should not be put aside, the 55 business model ideas represent a consistent starting point for the business model innovation process across all market sectors.

Based on this list of business model ideas, the developed heuristic methodology enabled in five steps the selection and organization of the applicable business model ideas into a conceptual business model solution space for Energy Hub concepts. As suggested by Gassmann et al. (2014), the developed 
methodology progresses through steps requiring alternatively diverging or converging thinking. The diverging phases promote the creation of a large number of possible solutions and thus an extension of the solution space. The converging phases aim to identify within the extended solution phase the most pertinent solutions. A number of consecutive diverging-converging iterations guide through the multidimensional problem and enable to find an appropriate solution. Hereafter, the five steps of the developed methodology (Figure 2) are explained and the results of their application presented.

\section{Filtering (Converging Thinking)}

In the first step, the 55 business model ideas are filtered considering two criteria. The first criterion is the general compatibility with the Energy Hub business: only the business model ideas potentially applicable to the Energy Hub business are kept. ${ }^{2}$

The second criterion was applied only to the ideas selected with the first criterion. This criterion regards the affinity with the different value chain activities of the business: the ideas were assigned to the value chain activities in which they are potentially applicable. ${ }^{3}$

As a result of these two criteria, 32 business model ideas are filtered and assigned to the different value chain activities, as represented in Table 1. The largest number of ideas refers to the Delivery of energy services and Pricing activities. The Operation and Control of infrastructures is characterized by only one business model idea and in the following will be associated with the Procurement of Infrastructures activity due to the close link between the two activities. Two business model ideas, Aikido and Performance based contracting, are relevant to two activities; all the other ideas are associated with only one activity. A short description of each business model ideas, taken from Gassmann et al. (2014), is available in the Supplementary Material.

\section{Compatibility (Diverging Thinking)}

Within the second step, the compatibility between the filtered business model ideas is systematically evaluated: the potential application of each business model idea in combination with every other individual business model idea within the same value chain activity is verified. The different value chain activities are considered fully independent to each other. As a result, a large number of possible combination of ideas are identified. These

\footnotetext{
${ }^{2}$ As an example, the business model idea E-Commerce, referring to the delivery of the value proposition through online channel only to reduce sales and distribution costs, has not been considered applicable for Energy Hubs and has not been retained. A further example on the application of the first criterion is the following one: the business model idea Open Source, referring to the free offer of a product with the purpose of gaining money with support and consulting; Razor and Blades, related to a free offer of a basic product requiring expensing consumable; and Lock-in, in which the customers are kept locked through high switching costs; have been considered substantially equivalent from the Energy Hub view point and only the idea Lock-in has been retained.

${ }^{3}$ For instance, the business model idea Crowdfunding, in which a crowd of investors finances the required investments, is assigned to the Procurement of Infrastructures activity. Likewise the idea Barter, referring to exchanging with customers goods with goods instead of money, is associate to the Pricing activity.
}

The Business Model Navigator (Gassmann et al. 2014) The 55 business model ideas

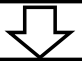

The heuristic methodology

I. Filtering (converging)

Table 1

- Selection of business model ideas compatible with Energy Hubs.

- Association of selected business model ideas to the compatible Energy Hub value chain steps.

II. Compatibility (diverging)

- Systematic compatibility evaluation of the selected business model ideas for each value chain step.

- Definition of all possible combinations of ideas.

III. Clustering (converging)

Table 2

- For each value chain step, clusters of compatible business model ideas are recognized.

IV. Combination (diverging)

- Creation of the business model patterns solution space consisting of all possible combination of clusters across the value chain.

V. Structuring (converging) Table 3

- The identified business model patterns are structured in a three dimensional solution space.

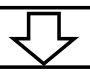

Energy Hub Business Model Solution Space

FIGURE 2 | The heuristic methodology

combinations create the solution space for the next convergent step of the methodology.

\section{Clustering (Converging Thinking)}

Based on the compatibility step II, in the third step, clusters containing only ideas compatible to each other are recognized per each value chain activity. The ideas bearing the largest number of incompatibilities and thus differentiating and strongly characterizing the clusters are recognized as dominant and are used to label the clusters. ${ }^{4}$ The results of this converging step are presented in Table 2. Reading Table 2 in vertical direction (i.e., going through the value chain steps), clusters contain business model ideas compatible to each other; while reading in horizontal direction (focusing on a single value chain step) clusters include incompatible business model ideas.

${ }^{4}$ Taking as example, the Delivery of Energy Services activity, the ideas No Frills, referring to delivering as basic as possible services; Experience Selling, referring to enrich the core value proposition with a comprehensive customer experience; and User Designed, in which the customers can tailor the value proposition, are recognized as not compatible to each other and are chosen to lead three different clusters. 
TABLE 1 | Filtered business model ideas.

\section{Value chain activities}

\section{Acquisition/loyalty}

by customers, partners, or EH

\section{Procurement of infrastructures}

by customers, partners, or EH

Operation and control of infrastructures

by customers, partners, or EH

Delivery of energy services

by customers, partners, or $\mathrm{EH}$

Pricing

managed by EH

Affiliation

Customer loyalty

Make more of it

Crowdfunding

Fractional ownership

Orchestrator

Aikido

Cross selling

Direct selling

Experience selling

Add-on

Aikido

Auction

Barter

Cash machine
Filtered business models

pen business mode

Rent instead of buying
Solution provider Two-sided-market Ultimate luxury

User designed

Performance-based

contracting

Revenue sharing

Subscription

TABLE 2 | Clusters of business model ideas.

Value chain activities

\section{Acquisition/loyalty}

by customers, partners, or EH

Procurement of infrastructure/operation and control by customers, partners, or $\mathrm{EH}$

Delivery of energy services

by customers, partners, or $\mathrm{EH}$
Fractional ownership

Crowdfunding

Open business model

Experience selling
Aikido
Cross selling
Direct selling
Guaranteed availability
Ingredient branding

Solution provider

Two-sided-market

Ultimate luxury

Pricing

managed by EH

Add-on
Aikido
Auction
Barter
Cash machine
Freemium
Hidden revenue
Lock-in
Pay what you want
Performance-based contracting
Revenue sharing

Clusters

Affiliation

Customer loyalty

Make more of it

Orchestrator

Open business model

Performance-based contracting

No frills

Aikido

Direct selling

Peer to peer

Two-sided-market

Pay per use

Aikido

Auction

Barter

Freemium

Hidden revenue

Lock-in

Pay what you want

Performance-based contracting

Revenue sharing
Rent instead of buying

Open business model

Performance-based contracting

\section{User designed}

Aikido

Cross selling

Direct selling

Guaranteed availability

Ingredient branding

Solution provider

Two-sided-market

Subscription

Aikido

Cash machine

Freemium

Hidden revenue

Lock-in

Pay what you want

Performance-based contracting

Revenue sharing
No cluster has been identified in Acquisition/Loyalty, due to the small number of business model ideas and their mutual compatibility. Three clusters per activity are identified on the other activities.

\section{Combination (Diverging Thinking)}

Combining a single cluster per each activity of the value chain it is possible to identify a number of potential business model patterns going across the whole Energy Hub value chain. All possible combinations of clusters represent the business model patterns solution space, which is structured within the last convergent step (V) of the methodology.

\section{Structuring (Converging Thinking)}

The possible clusters combinations identified in the previous step constitute the business model solution space. Within the last step of the methodology, the latter is structured in three 
dimensions: one represented by the Procurement and Control of Infrastructure, one represented by the Delivery of Energy Services, and one represented by the Pricing. In Table 3, the business model solution space is depicted in two of these three dimensions: the Procurement and Control of Infrastructures and the Delivery of Energy Services dimensions. On the Procurement of Infrastructures dimension (vertical axis), the business model options span from full Energy Hub's ownership of the infrastructure, through shared ownership, to full customer's (or partner's) ownership. On the Delivery of Energy Service dimension (horizontal axis), the available options span from high quality comprehensive services, through customized offers, to basic services.

Aiming to provide a reference orientation across the defined solution space, three reference business model patterns are selected (Pattern I, II, and III in Table 3). The third solution space dimension, the Pricing, is presented for each reference pattern within Table 3. Due to the higher flexibility characterizing the Pricing activity and for the sake of generality, each reference pattern features more than one Pricing cluster option.

In the next section, the three reference patterns are thoroughly analyzed and compared in order to put the developed conceptual framework into context through the use of examples.

\section{RESULTS AND DISCUSSION}

In the first part of Section "Results and Discussion," the reference business model patterns introduced in the previous section are thoroughly described and compared. In the second part, a number of examples of innovative business models recently implemented in the energy market are presented and their location within the defined solution space is discussed. Finally, at the end of the section, general outcomes are discussed.

\section{The Reference Business Model Patterns}

The conceptual business model solution space defined in the previous section is meant to support the Energy Hub business model innovation process at early stages. Potential stakeholders should determine the portion of the defined business model solution space more suitable for their intended Energy Hub concept through the selection of the most appropriate general business model pattern(s). This selection should be performed considering the determinants characterizing the intended Energy Hub concept, such as the customer segmentation, the available technical and financial resources, and external determinants (e.g., regulatory framework). Future works are expected to address the identification and impact of such determinants. Each general business model pattern comprises a collection of compatible business model ideas organized per value chain activity. Through combination, refinement, and adaptation of the identified business model ideas, the selected general business model pattern(s) can be tailored to the needs of the intended Energy Hub concept.

The reference business model patterns identified in the previous section aim to offer an orientation within the defined business model solution space. They have been selected to span across the whole solution space and thus to provide references easing the solution space characterization through examples.

Pattern I is based on the cluster Orchestrator associated with the Procurement and control of infrastructures value chain activities and on the cluster No Frills associated with the activity Delivery of energy services. Selected Pricing options are the clusters Pay per use and Subscription. Bottom line of this business model is to run the Energy Hub focusing on the operation and control and outsourcing the procurement of infrastructures. The Energy Hub's investment costs are low. The services offered to the customers focus on the essential. The related cost savings can be shared with the customers, which can benefit from low prices.

Pattern II is based on the cluster Fractional Ownership associated with the Procurement and control of infrastructures value chain activities, and on the cluster User Designed associated with the activity Delivery of energy services. All Pricing options are available: Add-on, Pay per use, and Subscription. Within this pattern, the Energy Hub shares the ownership of the infrastructures with one or multiple customers and offers the possibility of tailored energy services. The Energy Hub benefits from the infrastructure availability and from reduced investment costs and risks, which are partly or fully taken over by the customers. The customers can benefit from the possible valorization of their partly owned infrastructure while having access to complementary energy services provided by the Energy Hub.

Pattern III is based on the cluster Rent instead of buying associated with the Procurement and control of infrastructures value chain activities, and on the cluster Experience Selling associated with the activity Delivery of energy services. Selected Pricing options are the clusters Pay per use and Subscription. Within this business model pattern, the Energy Hub offers to the customer the possibility to lease all-inclusive turnkey solutions. The customers benefit from avoiding investments in the required infrastructure and from a complete and high quality customer

TABLE 3 | The business model patterns solution space and the reference patterns.

\begin{tabular}{|c|c|c|c|c|c|c|}
\hline \multirow{2}{*}{$\begin{array}{l}\text { Procurement of } \\
\text { infrastructure/operation } \\
\text { and control }\end{array}$} & & \multicolumn{5}{|c|}{ Delivery of energy services } \\
\hline & Fractional ownership & & \multicolumn{3}{|c|}{ Pattern II } & \\
\hline & & & Pay per use & Subscription & Add on & \\
\hline
\end{tabular}


experience. The Energy Hub is exposed to high investment costs that are met by the potentially high margins expected from the offered high quality services.

Hereafter, the reference patterns are analyzed following the business model terminology and conceptualization proposed by Osterwalder and Pigneur (2010) and Osterwalder et al. (2014). Their description of business models is coherent, extensively applied in the literature, and in particular in the energy sector (Okkonen and Suhonen, 2010; Richter, 2013). Osterwalder et al. (2014) defined a business model as "the rationale of how an organization creates, delivers, and captures value" and identified four main elements fully characterizing it: Value Proposition; Customers, including customer relationship, customer segments, and channels; Infrastructures, including key activities, key resources, and key partners; and Financial Viability, including cost structure and revenue stream.

The main features characterizing the three reference business model patterns analyzed and compared hereafter are summarized in Table 4.

\section{Value Proposition}

Pattern I main value proposition is to offer a multisided platform connecting consumers, prosumers, partners, and the energy market. The Energy Hub manages the energy exchanges and guarantees the availability of energy services to its customers.

Pattern II proposes tailored solutions fully adaptable to the customer infrastructures and needs. Depending on the customer owned infrastructure and preferences, the Energy Hub offers basic and complementary energy services with different level of participation.

Pattern III offers comprehensive turnkey solutions owned by the Energy Hub potentially going beyond traditional energy services and covering also closely related business opportunity such as domestic and mobility services. These products are offered to the customers with a complete service package to guarantee a high quality customer experience.

Customers of Pattern II and III could also benefit from a reduced exposition on external determinants (e.g., wholesale electricity markets) and improved energy security. This could be enabled by the higher level of self-sufficiency and flexibility ensured by the Energy Hub (co-)owned energy conversion/storage infrastructures.

\section{Customers}

Energy Hubs typically deal with segmented customers, potentially including residential buildings, commercial buildings, industries, and farms. Due to the required physical links with the customer, e.g. district heating grids, the geographical location of the Energy Hub represents its main attractiveness to customers.

Within this customer segmentation, Pattern I targets cost sensitive customers and prosumers owning the energy conversion infrastructures. The relationship with customers is regulated by automated exchanges based on established contracts. The multisided platform represents the main interface between customers and Energy Hub.

Pattern II addresses customers willing to participate to the investment in infrastructures. The customer relationship includes dedicated assistance in tailoring the value proposition offer and the creation of a community atmosphere fostering involvement of customers into the Energy Hub activity and development.

Pattern III aims to customers inclined to pay higher prices in order to profit of a high quality customer experience. The relationship with customers includes comprehensive support covering all aspects from the installation to the operation, maintenance, and replacement of the infrastructures in order to guarantee the promised comfort level. Within Pattern II and III customers are bound by long-term contracts aligned to the long amortization time of the investment in infrastructures afforded by the Energy Hub (Pattern III) or both the Energy Hub and the customers (Pattern II).

Customer's activities comprise consumption, production, and storage of energy, as well as internal energy trading if not contracted to the Energy Hub. Particularly for Pattern I and II customer's activities also include the maintenance of the owned infrastructure if not contracted to the Energy Hub.

Within Pattern I and II consumer's costs regard only the purchase of energy services. Prosumer's costs are associated with the amortization and maintenance of own (Pattern I) or partially own (Pattern II) infrastructures and to the purchasing costs of complementary energy services. Pattern III customer's costs simply regard the all-inclusive contract with the Energy Hub.

\section{Infrastructure}

Key resources of the Energy Hub are the energy conversion/storage and internal grid infrastructures, the required ICT systems, the personnel necessary to operate and maintain the infrastructure and responsible for the customer support, and the energy

TABLE 4 | Main features of the identified general business model patterns.

\begin{tabular}{|c|c|c|c|}
\hline & Pattern I & Pattern II & Pattern III \\
\hline & Orchestrator-No frills & Fractional ownership - User designed & Rent instead of buying - Experience selling \\
\hline $\begin{array}{l}\text { Value } \\
\text { proposition }\end{array}$ & $\begin{array}{l}\text { Multiside platform connecting consumers, } \\
\text { prosumers and energy market }\end{array}$ & $\begin{array}{l}\text { Tailored energy services adaptable and } \\
\text { complementary to customer infrastructures }\end{array}$ & $\begin{array}{l}\text { Comprehensive turnkey solutions going beyond } \\
\text { energy services }\end{array}$ \\
\hline Customers & $\begin{array}{l}\text { Cost sensitive customers } \\
\text { Prosumers owning the infrastructures }\end{array}$ & $\begin{array}{l}\text { Customers participating to the infrastructure } \\
\text { investments }\end{array}$ & $\begin{array}{l}\text { Customers inclined to pay higher prices to get } \\
\text { the best service quality }\end{array}$ \\
\hline Infrastructures & $\begin{array}{l}\text { No investment in infrastructures } \\
\text { Strong partnerships }\end{array}$ & Infrastructure ownership shared with customers & Owned infrastructures leased to customers \\
\hline Financial viability & Revenues from energy trading only & $\begin{array}{l}\text { Revenues from energy trading and service on } \\
\text { infrastructures }\end{array}$ & $\begin{array}{l}\text { Revenues from energy trading, leasing, and } \\
\text { additional services }\end{array}$ \\
\hline
\end{tabular}


trading. Depending on the business model pattern, the resources are (co-)owned, contracted from partners, or out of the scope of the Energy Hub.

In Pattern I, the Energy Hub does not invest in infrastructures and can focus its resources on strengthening its core activities of supplying energy services while keeping a more flexible structure compared to the other patterns.

In Pattern II, the ownership of the required infrastructures is shared between the Energy Hub and one or multiple customers. The Energy Hub develops tailored and flexible solutions enabling to incorporate and complement customer's infrastructures.

In Pattern III, the Energy Hub owns the required infrastructures and leases them to the customers. Additional infrastructures going beyond the supply of energy services and enriching the value proposition, e.g., domestic or mobility-related infrastructures could be additional key resources.

The Energy Hub key activities generally comprise the exchange of energy with and among customers (consumers and prosumers) and partners; and the continuous optimization of the operation of customer's, partners, and (co-)owned (Patterns II and III) infrastructures. The optimization aims to keep the internal grid balanced and to maximize the profit from energy trading. Specific activity of Pattern I is the continuous development of the multisided platform used as interface with the customers. For both Pattern II and III, additional key activities are the maintenance of the (co-)owned infrastructures and the strategic development of the Energy Hub infrastructures to continuously adapt to customer and partner acquisitions.

Key partners of the Energy Hub comprise: grid owners, ICT system providers, energy conversion/storage infrastructure providers, and suppliers of energy services/resources operating in the proximity (e.g., other Energy Hubs, or industries). Pattern I relies more on partnerships than Pattern II and III due to its peculiarity of not investing in infrastructures. Finally also financial institutions are key partners that offer financial instruments to support the investment in infrastructures of the Energy Hub (Patterns II and III), and of the customers (Patterns I and II).

\section{Financial Viability}

In the cost structure of the Energy Hub, fixed costs are related to: the overhead, the fixed expenses due to the contracts with partners, the maintenance of the multisided platform (Pattern I), the amortization and maintenance costs of the (partially-) owned or contracted infrastructures (Patterns II and III), and to the dedicated support services offered to the clients (Patterns II and III). Variable costs are mainly related to: the results of the energy trading, the grid charges, the exploitation of the partners' infrastructures (Pattern I), and to the energy resources used to operate the (partially-)owned or contracted infrastructures (Patterns II and III).

The Energy Hub revenue stream comprises: the revenues from the energy trading, which can be shared with prosumers and partners, the income related to the delivered energy to customers, and to the potential hidden revenues from partners interested in, e.g., accessing the demand and production profiles of the Energy Hub customers. Additionally, Pattern II benefits by the revenues from the provided maintenance of infrastructure, and Pattern III profits by the incomes from the infrastructure leased and from the comprehensive support services offered.

From a customer's and partner's perspective, all three patterns offer the possibility of valorizing investments in owned infrastructures through the access to the internal energy trading, or through external trading carried out by the Energy Hub organization. Within Pattern I and II consumer's costs regard only the purchase of energy services. Prosumer's costs are associated with the amortization and maintenance of own (Pattern I) or partially own (Pattern II) infrastructures and to the purchasing costs of complementary energy services. Pattern III customer's costs simply regard the all-inclusive contract with the Energy Hub.

\section{Innovative Market Implemented Business Models}

The need to face the currently very challenging energy market and its expected short-term evolution pushes utilities and more generally energy related companies to adapt their organizations and business models to gain competitiveness. The trend is especially noticeable in developed countries already characterized by a partially or fully liberalized market such as US and Germany. Policy makers urge to adapt the outdated existing regulatory framework to allow the exploitation of the emerging business opportunities. At European level a new Energy Market Design proposal is expected to come in the forthcoming months (European Commission, 2015b). Aim of this section is to present examples of innovative business models recently implemented in the market and allocate them to the most closely related region of the defined business model solution space (Table 5). The market review, partly based on the recent work of Fratzscher (2015), is not meant to be exhaustive. Instead, it aims to provide an overview across the different fields of opportunities related to the energy market and put into context the introduced conceptual framework. The analyzed business models are organized in four categories: focusing on demand management, focusing on generation, focusing on distribution, and focusing on value-added services.

\section{Demand Management}

The demand management side certainly represents a very active area offering a large spectrum of business opportunities aiming to support customers improving their energy efficiency. Even largest IT companies such as IBM, Oracle, and Google recognized the market potential on this sector and plunged into the market profiting on their capability of collecting and analyzing large number of data from the customers. Nest (2015) bought in 2015 by Google, is a well known example of innovative company offering smart devices providing energy management services. Other examples of innovative business model approaches focusing on demand management are as follows: Opower (2015) which offers to utility the interpretation of customers data with the aim to improve energy efficiency; Viridity Energy (2015) which support customers in valorizing demand side management capability in the wholesale energy market. Two interesting examples of companies providing innovative solutions through demand response and load management arise from Switzerland: Misurio (2015) an IBM supported company, provide solutions to 


\begin{tabular}{|c|c|c|c|c|}
\hline & & \multicolumn{3}{|c|}{ Delivery of energy services } \\
\hline & & No frills & User designed & Experience selling \\
\hline \multirow[t]{4}{*}{$\begin{array}{l}\text { Procurement of } \\
\text { infrastructure/ } \\
\text { operation and control }\end{array}$} & $\begin{array}{l}\text { Rent instead of } \\
\text { buying }\end{array}$ & & $\begin{array}{l}\text { E ON (E ON, 2015) } \\
\text { E ON (E ON, 2015) }\end{array}$ & $\begin{array}{l}\text { NRG (NRG, 2015) } \\
\text { Regio Energie Solothurn } \\
\text { (Regio Energie } \\
\text { Solothurn, 2015) } \\
\text { NRG (NRG, 2015) }\end{array}$ \\
\hline & Fractional ownership & Trianel Group (Trianel Group, 2015) & $\begin{array}{l}\text { Clean Energy Collectives (Clean Energy } \\
\text { Collectives, 2015) } \\
\text { Schwäbisch-Hall Stadtwerke } \\
\text { (Schwäbisch-Hall Stadwerke, 2015) }\end{array}$ & \\
\hline & & & Stroomversnelling (Stroomversnelling, 2015) & \\
\hline & Orchestrator & $\begin{array}{l}\text { Tiko (Tiko, 2015) } \\
\text { National Grid (National Grid, 2015) } \\
\text { Sun (SUN, 2015) } \\
\text { Next Kraftwerke (Next Kraftwerke, 2015) } \\
\text { Lichtblick (Lichtblick, 2015) } \\
\text { E2m (e2m, 2015) } \\
\text { Clean Energy Sourcing } \\
\text { Statkraft (Statkraft, 2015) }\end{array}$ & $\begin{array}{l}\text { Opower (Opower, 2015) } \\
\text { Viridity Energy (Viridity Energy, 2015) } \\
\text { Misurio (Misurio, 2015) } \\
\text { Austin Energy (Austin Energy, 2015) } \\
\text { Repower (Repower, 2015) } \\
\text { WGL (WGL Energy, 2015) } \\
\text { YelloStrom (EnBW, 2015) }\end{array}$ & Nest (Nest, 2015) \\
\hline
\end{tabular}

Business model categories: demand management/distribution/generation/added services.

optimize the operation of multi-energy networks of distributed energy conversion systems Tiko (2015); a spinoff of the largest Swiss telecommunication company Swisscom, offer the possibility to small to large customers to connect in a storage network and valorized their aggregated flexibility into the power reserve and balancing market.

As highlighted in Table 5, innovative business models focusing on demand management are commonly characterized by lean structures, associable to Pattern I, addressing the operation of customer's owned infrastructures. However on the Delivery of Energy Services side, they extensively cover the range of possibilities offering from basic to tailored comprehensive packages of services.

\section{Distribution}

On the distribution side, new business opportunities arise from the needs of low voltage distributed smart grids bidirectionally connecting prosumers and consumers to the higher voltage grid infrastructure. However, the success of this typology of business models strongly depends upon the development of a regulatory framework more suitable to competitiveness. A number of utility companies substantially reoriented their core business activity toward the distribution of energy services. In US, an emblematic example is the strategy adopted by National Grid (2015) of upgrading the grid infrastructure to foster the integration of smart technologies appealing to customers. In Germany, Trianel Group (2015) aims to bundling resources purchasing networks and strengthening through aggregation small municipality utilities. The local utility SUN (2015) supports the integration of distributed renewable generation units providing network capability and management options to small players characterized by limited resources.

Innovative distribution focused business models aim to provide to customers infrastructures access to the distribution network. They provide rather basic services and operate as a twosided platform connecting distributed generation to grid operators (Table 5). They can be generally associated with Pattern I.

\section{Generation}

The transition from centralized generation toward distributed generation implies the development of innovative business model approaches focused on the generation side. A first example is the development of business model to promote the diffusion and integration of many small-scale distributed generation units. In US, utilities offer leasing solutions for solar generation and storage systems including, installation, operation, and maintenance. Alternatively they lease customer's roofs to install and operate distributed small-scale solar-based generation units (NRG, 2015). In Switzerland, Regio Energie Solothurn (2015) offers long-term leasing solution for photovoltaic installations. At the contract expiration, the equipment ownership passes to the customer without additional fee.

Another diffused option in US and Germany [e.g., SchwäbischHall Stadwerke (2015); Clean Energy Collectives (2015)] is solar or wind community projects led by utilities where customers share investments and benefits of common infrastructures operated by the utilities. Furthermore in Germany, large utilities [e.g., E ON (2015)] offer to completely handle regional renewable energy projects on behalf of customers such as local utilities.

Many examples can be found also on new business model concepts focusing on supporting customer sited small-scale generation units. In US, the municipality utility company of Austin (Austin Energy, 2015) proposes remuneration mechanism going beyond the per kilowatt-hour fees and including other benefits such as avoided fuel and infrastructure costs, energy price hedging, and environmental values. In Germany, new companies [e.g., (Next Kraftwerke, 2015; e2m, 2015; Lichtblick, 2015)] offer the possibility of connecting customers in virtual power plants 
balancing the volatility characterizing renewable energies and reaching the critical size needed to participate to the power reserve and balancing market.

Generation-oriented business models span across the entire solution space and in particular reflect the three reference business patterns identified. However, the tendency toward business models focusing on operation of customer's owned infrastructures and to offer customized services emerges clearly (Table 5).

\section{Value-Added Services}

Traditional utility business models successfully operated for a long time without the need of focusing on customer's needs. Today, a large number of business opportunities focusing on added-value services tailored to the customers are emerging.

The diversification of the offer allows targeting more customer segments and improving the market positioning with respect to the competitors. Yello Strom of EnBW (2015) in Germany, Repower (2015) in Switzerland and WGL Energy (2015) in US are examples of utilities offering a large variety of green power packages allowing the customer to personalize their electricity procurements and tariffs depending on their need and conviction.

Opening up the offer portfolio to additional services and targeting niche of customers with very specific needs emerge as another promising business strategy. Providing e-mobility services and support in the installation of distributed energy conversion infrastructures is the strategy applied by NRG (2015) in US. The largest utilities in Germany provide tailored turnkey solutions to commercial and industrial customers providing planning, construction, operation and maintenance of the energy related infrastructures [e.g., E ON (2015)]. On a different scale, smaller utilities such as Statkraft (2015) and Clean Energy Sourcing (2015) provide direct marketing to facilitate small customer to access the wholesale market.

The Stroomversnelling (2015) program in The Netherlands is an interesting example of innovative business model focusing on building retrofit. The renovation of existing buildings appears as a high potential and very challenging market for the years to come. Within Stroomversnelling program, a consortium of construction companies and housing cooperatives retrofits in a very short time poorly efficient rental housing from the 1950s-70s to netzero buildings. With the applied business model, the investment is paid back only through the energy savings realized and with no additional charges on the tenants.

Added-value services oriented business models follow the same tendency as generation oriented business models. They cover the whole solution space with a slight tendency on favoring customized services and management of third party owned infrastructures (Table 5).

\section{Discussion}

The presented market analysis allowed identifying the regions of the business model solution space most commonly adopted for each different category of emerging business successfully implemented at this stage of the energy transition.

Demand management and distribution oriented businesses favor operation and control focused business models and to provide basic (distribution) or tailored (demand management) services to the customers. Generation and added-value services-oriented business models cover more uniformly the whole business model solution space. However, a tendency on favoring business models focusing on operation and control of third party owned infrastructures and providing solution tailored to the customers emerge clearly in all business model categories. As a result, the intersection between Pattern I and II appears as the area of the business model solution space where the energy transition is principally addressing the market at the moment. This tendency is in contrast with traditional vertical integrated centralized generation business models, which mainly focus on owned infrastructures and delivery of standard services (Bhattacharyya, 2011). The energy transition is decentralizing the energy conversion and storage infrastructures at the customer's place and centralizing the customers at the core of the business model. This consideration is fully aligned with the findings proposed by Richter $(2012,2013)$ suggesting that utilities should strategically orient toward customer-side business models, and with the vision of the recently adopted European Energy Union Strategy (European Commission, 2015a). This initiative and the consequently related activities (European Commission, 2015b) emerge as a suitable framework to tackle the challenge of designing new flexible regulatory frameworks removing the existing market barriers that hinder the costumers from becoming protagonists in fostering the energy transition.

Interpreting the results from a different perspective, the empty (or less crowded) spots of the business model solution space depicted in Table 5 represent the currently untapped opportunities. The fact that emerging businesses generally prefer not to focus on the ownership of the infrastructures and on potentially more profitable high quality services suggests that, at present, large investments from firms are discouraged. Needless to say, this consideration is compatible with the current global economic slowdown and changing regulatory frameworks (Masini and Menichetti, 2012; Wüstenhagen and Menichetti, 2012). Assuming the next step of the energy transition being characterized by a less uncertain and more suitable regulatory framework, and in the context of a global economic recovery, the potentially more profitable business opportunities focusing on infrastructure leasing solutions and high quality services are expected to become more appealing.

\section{CONCLUSION}

The present study introduces a heuristic methodology easing the identification of general business model patterns best suited for general Local Energy Management concepts such as Energy Hubs. A conceptual framework characterizing the Energy Hub business model solution space is developed. The conceptual framework aims to ease the business model innovation process at early stages. Stakeholders should identify within the defined solution space the most appropriate general pattern(s) matching the intended Energy Hub concept. Each general business model pattern consists in an organized collection of business model ideas that can be combined to develop a specific business model tailored to the intended Energy Hub concept. 
The defined business model solution space is put into context through the analysis and comparison of three reference business model patterns. The three reference patterns are selected to provide an orientation across the whole business model solution space.

Furthermore, a review of successfully market implemented innovative business models in the different value chain steps of the energy services sector is proposed. The location of the presented business models within the defined conceptual business model solution space is discussed.

On the one hand, the analysis outlined as in contrast with traditional centralized generation business models, focusing on procurement of infrastructure and delivery of standardized service as core activities, emerging business models mainly focus on operation and control of third party owned infrastructures and on customized services. The energy transition is bringing the customers at the core of the business models. On the other hand, the analysis highlighted as at present emerging business models disfavor the options of offering infrastructure leasing solutions and high quality comprehensive services. These untapped business opportunities, requiring higher investments and potentially more profitable, are expected to become more appealing when a more suitable regulatory frameworks will be in place and the global economic situation will improve.

Potential Energy Hub stakeholders should benefit from this contribution by finding inspiration to move forward from the attempts of adapting business models conceived for the traditional centralized generation, to instead create from scratch innovative business model valorizing the peculiarities of decentralized energy systems.

The outcomes of this work offer insights for policy makers on challenges and opportunities related to Energy Hub concepts. Policies establish the boundary conditions for business model developments. Therefore, they have a preeminent impact on the business model innovation process, especially at early stage. The role of policy makers is twofold. On the one hand, existing energy policies conceived to regulate the traditional energy market should be reviewed in order to avoid to hinder the business model innovation process. On the other hand, future policies should embrace the heterogeneity of distributed generation by creating an appropriately flexible regulatory framework. In this perspective, the proposed conceptual business model solution space aim to

\section{REFERENCES}

Allan, G., Eromenko, I., Gilmartin, M., Kockar, I., and McGregor, P. (2015). The economics of distributed energy generation: a literature review. Renew. Sustainable Energy Rev 42, 543-556. doi:10.1016/j.rser.2014.07.064

Austin Energy. (2015). Available at: https://www.austinenergy.com/ [accessed July $21,2015]$

Bhattacharyya, S. C. (2011). Energy Economics Concepts, Issues, Markets and Governance. London: Springer.

Bucherer, E., Eisert, U., and Gassmann, O. (2012). Towards systematic business model innovation: lessons from product innovation management. Creat. Innovat. Manage. 21, 183-198. doi:10.1111/j.1467-8691.2012.00637.x

Capuder, T., and Mancarella, P. (2014). Techno-economic and environmental modelling and optimization of flexible distributed multi-generation options. Energy 71, 516-533. doi:10.1016/j.energy.2014.04.097

Chesbrough, H. (2010). Business model innovation: opportunities and barriers. Long Range Plann. 43, 354-363. doi:10.1016/j.lrp.2009.07.010 provide to policy makers indications on the full spectrum of business model patterns potentially applicable in Energy Hub concepts. The development of new policies fostering the penetration of Local Energy Management should primarily focus on the preeminent role of customers. The regulatory framework coordinating the relation between the wholesale and retail energy markets should be redefined to enable/facilitate the access of customers (or aggregation of customers) to the new arising business opportunities. New policies should enable the development of business models focusing on customer tailored solutions and potentially including services going across other market segments (e.g., including mobility, home automation and security, telecommunication services). Furthermore, the dissemination of Local Energy Managements is expected to take major advantages from shared ownership based business models. For this reason, policy makers should encourage such approaches that were not considered, or considered to a minor extend, within the in force regulatory frameworks. Finally, policy makers should improve the attractiveness of Local Energy Management to large investments from private companies. In this perspective, the development of new regulatory frameworks clear, stable, and consistent across the time period necessary to achieve the long-term sustainability targets is expected to be beneficial.

\section{AUTHOR CONTRIBUTIONS}

EF: main author, main contributions to the conception and realization of the work. SS: substantial contribution to conception and realization of the work, and critical revision of the work.

\section{ACKNOWLEDGMENTS}

This work has been accomplished in the frame of the Swiss Competence Center for Energy Research on Future Energy Efficient Buildings \& Districts SCCER FEEB\&D, funded by The Commission for Technology and Innovation of the Swiss Confederation.

\section{SUPPLEMENTARY MATERIAL}

The Supplementary Material for this article can be found online at http://journal.frontiersin.org/article/10.3389/fenrg.2016.00007

Clean Energy Collectives. (2015). Available at: http://www.easycleanenergy.com [accessed July 21, 2015].

Clean Energy Sourcing. (2015). Available at: http://www.clens.eu [accessed July $21,2015]$.

Curtius, H. C., Künzel, K., and Loock, M. (2012). Generic customer segments and business models for smart grids. Der Markt 51, 63-74. doi:10.1007/ s12642-012-0076-0

e2m. (2015). Available at: http://www.energy2market.de [accessed July 21, 2015]. EnBW. (2015). Available at: https://www.enbw.com [accessed July 21, 2015]. E ON. (2015). Available at: https://www.eon.com [accessed July 21, 2015].

European Commission. (2011). COM/2011/0885 Energy Roadmap 2050. Brussels: EU. European Commission. (2012). Directive 2012/27/EU of the European Parliament and of the Council of 25 October 2012 on Energy Efficiency. Brussels: EU.

European Commission. (2014). COM/2014/015 A Policy Framework for Climate and Energy in the Period from 2020 to 2030. Brussels: EU.

European Commission. (2015a). COM/2015/080 A Framework Strategy for a Resilient Energy Union with a Forward-Looking Climate Change Policy. Brussels: EU. 
European Commission. (2015b). Commission Proposes "New Deal" for Energy Consumers, Redesign of Electricity Market and Revision of Energy Label for More Clarity. Press Release. Available at: https://ec.europa.eu/energy/en/news/ new-electricity-market-consumers [accessed July 15, 2015].

Facchinetti, E., Favrat, D., and Marechal, F. (2014). Design and optimization of an innovative solid oxide fuel cell-gas turbine hybrid cycle for small scale distributed generation. Fuel Cells 14, 595-606. doi:10.1002/fuce.201300196

Fratzscher, S. (2015). The Future of Utilities: Extinction or Re-Invention? A Transatlantic Perspective. Berlin: Heinrich Böll Stift.

Frei, C. W. (2008). What if...? Utility vision 2020. Energy Policy 36, 3640-3645. doi:10.1016/j.enpol.2008.07.016

Gassmann, O., Enkel, E., and Chesbrough, H. (2010). The future of open innovation. Res. Dev. Manage. 40, 213-221. doi:10.1111/j.1467-9310.2010.00605.x

Gassmann, O., Frankenberger, K., and Csik, M. (2014). The Business Model Navigator. Upper Saddle River, NJ: FT Press.

Geidl, M., Koeppel, G., Favre-Perrod, P., Klockl, B., Andersson, G., and Frohlich, K. (2007). Energy hubs for the future. IEEE Power Energy Mag. 5, 24-30. doi:10.1109/MPAE.2007.264850

Graves, C., Ebbesen, S. D., Mogensen, M., and Lackner, K. S. (2011). Sustainable hydrocarbon fuels by recycling $\mathrm{CO} 2$ and $\mathrm{H} 2 \mathrm{O}$ with renewable or nuclear energy. Renew. Sustain. Energy Rev. 15, 1-23. doi:10.1016/j.rser.2010.07.014

IEA. (2002). Distributed Generation in Liberalised Electricity Markets. Paris: OECD/ International Energy Agency (IEA).

IEA. (2014). World Energy Outlook 2014. Paris: OECD/International Energy Agency (IEA).

Karger, C. R., and Hennings, W. (2009). Sustainability evaluation of decentralized electricity generation. Renew. Sustain. Energy Rev. 13, 583-593. doi:10.1016/j.rser.2007.11.003

Lichtblick. (2015). Available at: http://www.lichtblick.de [accessed July 21, 2015].

Loock, M. (2012). Going beyond best technology and lowest price: on renewable energy investors' preference for service-driven business models. Energy Policy 40, 21-27. doi:10.1016/j.enpol.2010.06.059

Mancarella, P. (2014). MES (multi-energy systems): an overview of concepts and evaluation models. Energy 65, 1-17. doi:10.1016/j.energy.2013.10.041

Masini, A., and Menichetti, E. (2012). The impact of behavioural factors in the renewable energy investment decision making process: conceptual framework and empirical findings. Energy Policy 40, 28-38. doi:10.1016/j.enpol.2010.06.062

Misurio. (2015). Available at: http://www.misurio.ch [accessed July 21, 2015].

National Grid. (2015). Available at: https://www.nationalgridus.com/ [accessed July 21, 2015].

Nest. (2015). Available at: https://nest.com [accessed July 21, 2015].

Next Kraftwerke. (2015). Available at: https://www.next-kraftwerke.de [accessed July 21, 2015].

NRG. (2015). Available at: http://www.nrg.com [accessed July 21, 2015].

Okkonen, L., and Suhonen, N. (2010). Business models of heat entrepreneurship in Finland. Energy Policy 38, 3443-3452. doi:10.1016/j.enpol.2010.02.018

Opower. (2015). Available at: http://www.opower.com [accessed July 21, 2015].

Orehounig, K., Evins, R., and Dorer, V. (2015). Integration of decentralized energy systems in neighbourhoods using the energy hub approach. Appl. Energy 154, 277-289. doi:10.1016/j.apenergy.2015.04.114

Orehounig, K., Mavromatidis, G., Evins, R., Dorer, V., and Carmeliet, J. (2014). Towards an energy sustainable community: an energy system analysis for a village in Switzerland. Energy Build. 84, 277-286. doi:10.1016/j.enbuild.2014.08.012

Osterwalder, A., and Pigneur, Y. (2010). Business Model Generation: A Handbook for Visionaries, Game Changers, and Challengers. Hoboken, NJ: Wiley.
Osterwalder, A., Pigneur, Y., Bernarda, G., and Smith, A. (2014). Value Proposition Design: How to Create Products and Services Customers Want. Hoboken, NJ: Wiley.

Parisio, A., Del Vecchio, C., and Vaccaro, A. (2012). A robust optimization approach to energy hub management. Int. J. Electr. Power Energy Syst. 42, 98-104. doi:10.1016/j.ijepes.2012.03.015

Porter, M. E. (1985). The Competitive Advantage: Creating and Sustaining Superior Performance. New York, NY: Free Press.

Regio Energie Solothurn. (2015). Available at: http://www.regioenergie.ch [accessed July 21, 2015].

Repower. (2015). Available at: http://www.repower.com [accessed July 21, 2015].

Richter, M. (2012). Utilities' business models for renewable energy: a review. Renew. Sustain. Energy Rev. 16, 2483-2493. doi:10.1016/j.rser.2012.01.072

Richter, M. (2013). Business model innovation for sustainable energy: German utilities and renewable energy. Energy Policy 62, 1226-1237. doi:10.1016/j. enpol.2013.05.038

Schleicher-Tappeser, R. (2012). How renewables will change electricity markets in the next five years. Energy Policy 48, 64-75. doi:10.1016/j.enpol.2012.04.042

Schwäbisch-Hall Stadwerke. (2015). Available at: http://www.stadtwerke-hall.de [accessed July 21, 2015].

SFOE. (2012). Analyse des schweizerischen Energieverbrauchs 2000-2012 nach Verwendungszwecken [Energy Consumption in Switzerland According to Purpose 2000-2012]. Bern: Swiss Federal Office of Energy.

Statkraft. (2015). Available at: http://www.statkraft.de [accessed July 21, 2015].

Stroomversnelling. (2015). Available at: http://www.stroomversnelling.net [accessed July 21, 2015].

Sühlsen, K., and Hisschemöller, M. (2014). Lobbying the "Energiewende." Assessing the effectiveness of strategies to promote the renewable energy business in Germany. Energy Policy 69, 316-325. doi:10.1016/j.enpol.2014.02.018

SUN. (2015). Available at: http://www.sun-stadtwerke.de [accessed July 21, 2015].

Tiko. (2015). Available at: https://tiko.ch [accessed July 21, 2015].

Trianel Group. (2015). Available at: http://www.trianel.com [accessed July 21, 2015].

Viral, R., and Khatod, D. K. (2012). Optimal planning of distributed generation systems in distribution system: a review. Renew. Sustain. Energy Rev. 16, 5146-5165. doi:10.1016/j.rser.2012.05.020

Viridity Energy. (2015). Available at: http://viridityenergy.com [accessed July 21, 2015].

Weber, C., and Favrat, D. (2010). Conventional and advanced CO2 based district energy systems. Energy 35, 5070-5081. doi:10.1016/j.energy.2010.08.008

WGL Energy. (2015). Available at: http://www.wges.com [accessed July 21, 2015].

Wüstenhagen, R., and Menichetti, E. (2012). Strategic choices for renewable energy investment: conceptual framework and opportunities for further research. Energy Policy 40, 1-10. doi:10.1016/j.enpol.2011.06.050

Conflict of Interest Statement: The authors declare that the research was conducted in the absence of any commercial or financial relationships that could be construed as a potential conflict of interest.

Copyright (C) 2016 Facchinetti and Sulzer. This is an open-access article distributed under the terms of the Creative Commons Attribution License (CC BY). The use, distribution or reproduction in other forums is permitted, provided the original author(s) or licensor are credited and that the original publication in this journal is cited, in accordance with accepted academic practice. No use, distribution or reproduction is permitted which does not comply with these terms. 